DOI 10. 18307/2021. 0314

(c) 2021 by Journal of Lake Sciences

\title{
贵州高原花溪水库浮游植物优势种生态位及种间联结性动态分析”
}

\author{
马一明 ${ }^{1,2}$,李秋华 ${ }^{1,2 * *}$, 潘少朴 ${ }^{1,2}$, 旷 攀 ${ }^{1,2}$,金 爽 ${ }^{1,2}$ \\ ( 1 : 贵州师范大学贵州省山地环境信息系统和生态环境保护重点实验室, 贵阳 550001) \\ (2: 贵州省国际合作研究基地-水生态国际联合研究中心,贵阳 550001)
}

\begin{abstract}
摘 要: 为了解贵州高原花溪水库在 2017 年 3 月生态调控蓝藻水华后, 浮游植物物种多样性结构的稳定状况, 于 2017 年 4 月- 2018 年 1 月 4 个季节对花溪水库的浮游植物群落结构进行调查. 运用生态位宽度、生态位重叠值、方差比率法、卡 方检验和联结系数对主要浮游植物群落间的相互关系进行综合分析. 结果表明:4 个季节共出现优势种 4 门 11 种, 其中 硅藻门的尖针杆藻 (Synedra acusva) 和梅尼小环藻 (Cylotella meneghiniana) 在 4 个季节都为优势种, 对水环境状态指示明 显. 各优势种的生态位宽度差异较大, 变化范围为 $0.120 \sim 0.814$, 主要由广生态位种和窄生态位种组成. 种对间生态位重 叠值的变化范围为 $0.101 \sim 0.936$, 生境越相似的种对重叠值越大. 方差比率法结果分析显示, 优势种对间总体呈显著正关 联. 通过卡方检验后发现 38 对藻种中联结性显著的有 9 对, 主要分布在夏、秋季, 体现了花溪水库群落结构受人为干扰和 季节变化的影响较大, 呈“不稳定一稳定一不稳定”的交叉演替模式.
\end{abstract}

关键词: 浮游植物; 优势种; 生态位; 种间联结;花溪水库

\section{Dynamic analysis of niche and interspecific association of dominant phytoplankton species in Huaxi Reservoir of Guizhou Plateau*}

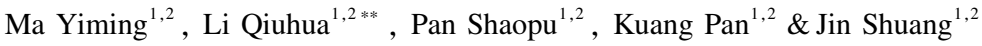 \\ (1: Key Laboratory for Information System of Mountainous Area and Protection of Ecological Environment of Guizhou Prov- \\ ince, Guizhou Normal University, Guiyang 550001, P.R.China) \\ (2: Guizhou International Cooperative Research Base-International Joint Research Center for Water Ecology, Guiyang \\ 550001, P.R.China)
}

\begin{abstract}
In order to understand the stability of the phytoplankton species diversity structure of the Huaxi Reservoir on the Guizhou Plateau after the ecological regulation of cyanobacteria blooms in March of 2017, the phytoplankton community structure of Huaxi Reservoir was investigated in the four seasons from April 2017 to January 2018. The relationship between the main phytoplankton communities was comprehensively analyzed using niche width, niche overlap, variance ratio method, Chi-square test, and connection coefficient. The results showed that there are 4 Phylum and 11 Genus in four seasons, among which Synedra acusva and Cylotella meneghiniana were the dominant species in 4 seasons, which indicate the state of the water environment. The niche width of each dominant species is quite different, the variation range is $0.120-0.814$, mainly composed of wide niche species and narrow niche species. Niche overlap between species pairs varies from 0.101 to 0.936 , the more similar the habitat, the greater the overlap value. Variance ratio method analysis shown that the dominant species pairs are generally positively correlated. The Chi-square test shows that 9 pairs of 38 pairs of algae species are significantly connected, mainly distributed in summer and autumn, reflecting the great influence of human disturbance and seasonal changes on the community structure of Huaxi Reservoir, showing a cross succession model of "unstable-stable-unstable".
\end{abstract}

Keywords: Phytoplankton; dominant species; niche; interspecies association; Huaxi Reservoir

* 2020-06-23 收稿;2020-08-28 收修改稿.

国家自然科学基金项目 (U1612442) 和贵州省科技厅项目（黔科合平台人才[2020]6009、[2018]5805 和黔科合支 撑 [2020]4Y009 号) 联合资助.

** 通信作者;E-mail:qiuhua2002@126.com. 
浮游植物是水生态系统中重要的初级生产者和食物链的起点,作为水库和湖泊生态系统的重要组成部 分, 对区域生态环境特征具有重要的指示作用 ${ }^{[1]}$,其群落结构特征的时序变化性能反映水质状况, 因而常被 用作评价湖泊生态状况的重要指标 ${ }^{[2-3]}$. 相对于浮游植物其他种群, 优势种群的演替和生物量的时空变化更 能直观反映水质的变化过程 ${ }^{[4]}$.

生态位 (niche) 作为生态学研究的核心热点之一, 对于研究种间关系、群落结构、物种多样性和群落动态 演替等方面有着重要的参考价值 ${ }^{[5]}$. 生态位宽度是反映物种利用生境内不同资源状态能力的体现 ${ }^{[6]}$. 生态 位重叠是指不同物种在同一空间分布上共同竞争资源的现象, 当两个物种适应于同一营养成分、空间等资 源状态时, 就会出现生态位重叠现象 ${ }^{[7]}$. 利用生态宽度和生态位重叠等方面的理论体系, 汪志䏲等 ${ }^{[8]}$ 用来预 测水华暴发的预警系统已有较好的成果. 研究种群的生态位特征和种间联结性, 还能更好地认识水生态系 统中浮游植物之间的相互关系, 对揭示浮游植物种群间共存机制和与水生环境之间的响应关系具有十分重 要的意义 ${ }^{[9]}$.

花溪水库属于典型的喀斯特高原深水水库, 地处贵阳市花溪区, 位于南明河上游花溪河段, 是贵阳市主 要的饮用水资源之一. 由于花溪区城市化进程迅速发展, 导致水环境极具恶化. Wang 等 ${ }^{[10]}$ 于 2015 年 8 月对 花溪水库沉积物的多环芳烃进行检测发现, 部分烃基含量过高, 具有严重的生态风险. 2017 年 3 月花溪水库 则暴发了长达 $30 \mathrm{~d}$ 的水华束丝藻 (Aphanizomenon flosaquae) 的水华, 在通过使用无毒高效生态除藻剂 ( HP-I 号) 除藻和采用物理隔离工程措施, 实施持续 $60 \mathrm{~d}$ 的生态调控后, 水华得到了有效控制, 但也使得浮游植物 的群落结构发生了改变 ${ }^{[11]}$. 为了解花溪水库在生态调控后浮游植物物种多样性结构及其适应性, 本文对花 溪水库生态位和种间联结性进行了研究, 揭示了一年内不同季节下浮游植物群落中各物种种间相互依存和 竞争关系以及种间替代和共存关系的演变机制, 以期明确花溪水库浮游植物群落结构和分布特征, 为预测 浮游植物群落结构变化的趋势提供依据, 达到预防水华再次发生的目的.

$106^{\circ} 35^{\prime} 50^{\prime \prime} \mathrm{E} \quad 106^{\circ} 36^{\prime} 40^{\prime \prime} \mathrm{E} \quad 106^{\circ} 37^{\prime} 30^{\prime \prime} \mathrm{E} \quad 106^{\circ} 38^{\prime} 20^{\prime \prime} \mathrm{E}$

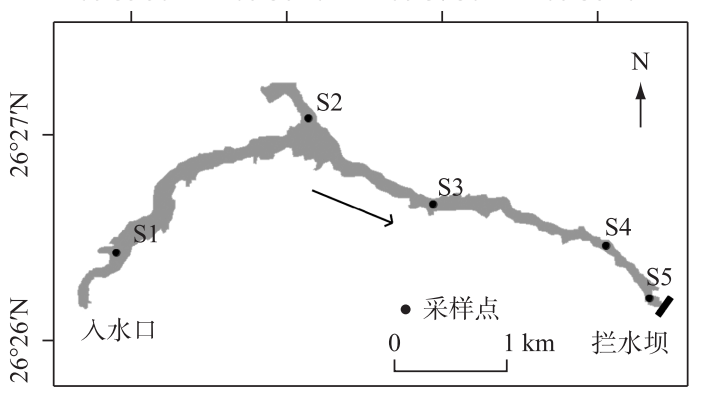

图 1 花溪水库采样点分布

Fig.1 Distribution of sampling sites in Huaxi Reservoir

\section{1 材料与方法}

\section{1 调查方法}

花溪水库位于南明河上游花溪河段, 地处贵 阳市花溪区, 年均气温 $14.9^{\circ} \mathrm{C}$, 其流域面积为 315 $\mathrm{km}^{2}$, 正常蓄水位 $1140 \mathrm{~m}$, 最高水深 $33 \mathrm{~m}$, 平均水 深为 $9.5 \mathrm{~m}$, 相应库容为 $2.3 \times 10^{7} \mathrm{~m}^{3}$. 该研究于 2017 年 4 月 5 日 (春季)、7月 11 日 (夏季)、10月 23 日 (秋季) 和 2018 年 1 月 15 日 (冬季) 对花溪 水库浮游植物群落结构进行调查. 根据《湖泊富 营养调查规范》 ${ }^{[12]}$ 与花溪水库水域特点及生态调 控区域设置 $\mathrm{S} 1 \sim \mathrm{S} 5$ 共 5 个采样点 (图 1), 每个采 样点分为 3 层, 即表层 $(0.5 \mathrm{~m})$ 、中层 $(5 \mathrm{~m})$ 、下层

$(10 \mathrm{~m})$ 收集浮游植物和水质指标样品.

\section{2 样品的采集与处理}

浮游植定量样品: 在每个采样点的表层、中层和下层各取 $1.5 \mathrm{~L}$ 的水样, 立刻加人 $15 \mathrm{~mL}$ 鲁哥氏液固定, 带回实验室静置 $24 \sim 48 \mathrm{~h}$ 后用虹吸法浓缩至 $30 \mathrm{~mL}$, 再使用 $0.1 \mathrm{~mL}$ 浮游生物计数框在光学显微镜下进行观 察、鉴定和计数. 鉴定工作参考的主要资料为《中国淡水藻类——系统、分类及生态》 ${ }^{[13]}$ 及中国内陆水域常 见藻类图谱》 ${ }^{[14]}$ 等.

现场使用雷磁水质检测仪测定水温 (WT)、溶解氧 ( DO) 和 $\mathrm{pH}$ 等水质参数, 采用黑白盘测定透明度 (SD). 按照《地表水环境质量标准》( GB 3838－2002) 对各项理化指标进行测定, 包括总磷 ( TP)、总氮 $(\mathrm{TN})$ 、溶解性总氮 $\left(\mathrm{DIN}\right.$, 包括硝态氮 $\left(\mathrm{NO}_{3}^{-}-\mathrm{N}\right)$ 、亚硝态氮 $\left(\mathrm{NO}_{2}^{-}-\mathrm{N}\right)$ 、氨氮 $\left.\left(\mathrm{NH}_{3}-\mathrm{N}\right)\right)$ 、正磷酸盐 $\left(\mathrm{PO}_{4}^{3-}-\mathrm{P}\right)$ 、高 锰酸盐指数 $\left(\mathrm{COD}_{\mathrm{Mn}}\right)$ 等, 叶绿素 $a(\mathrm{Chl} . a)$ 浓度使用丙酮萃取法测定 ${ }^{[15]}$. 


\section{3 数据分析}

利用优势度指数 $(Y)^{[16]}$ 、生态位宽度 $\left(B_{i}\right)^{[17]}$ 、生态位重叠值 $\left(O_{i k}\right)^{[18]}$ 、方差比率法 $(V R)$ 检验物种间总 体关联性 ${ }^{[19]}$, 对藻类群落结构时空分布的变化规律进行探索与预测, 其公式分别为:

$$
\begin{gathered}
Y=\frac{n_{i}}{N} f_{i} \\
B_{i}=1 / r \cdot \sum_{j=1}^{r} P_{i j}^{2} \\
O_{i k}=\frac{\sum_{j=1}^{r}\left(P_{i j} \cdot P_{k j}\right)}{\sum_{j=1}^{r} P_{i j}^{2} \cdot \sum_{j=1}^{r} P_{k j}^{2}} \\
\Delta O_{i k}=\sum_{k=1} O_{i k}-\sum_{i=1} O_{i k} \\
R=\frac{B_{i}}{\Delta O_{i k}}(i=k) \\
\delta T^{2}=\sum_{i=1}^{S} P_{i}\left(1-P_{i}\right)^{2} \\
S T^{2}=\frac{1}{N} \sum_{j=1}^{N}\left(T_{j}-t\right)^{2} \\
V R=\frac{S T^{2}}{\delta T^{2}}
\end{gathered}
$$

式中, $n_{i}$ 为样点中第 $i$ 种浮游植物的个体数, $N$ 为样点中浮游植物的总和, $f_{i}$ 为该种属在各样点中出现的频率. 其中 $Y \geqslant 0.02$ 的藻类确定为优势藻种, $Y>0.1$ 为绝对优势种; $B_{i}$ 为物种的生态位宽度, $P_{i j}=n_{i j} / N_{i}$ 表示物种 $i$ 在第 $j$ 个资源状态 (即采样点) 下的个体数占该种所有个体数的比例. $n_{i j}$ 为种群 $i$ 利用资源状态 $j$ 的数量, $N_{i}$ 为种群 $i$ 的总数量, $r$ 为资源状态总数; $\delta T^{2}$ 表示物种出现在所有采样点中的方差, $S T^{2}$ 表示总种数出现频率的 方差,检验值 $V R$ 表示物种间总体的关联形式.

最后采用 Yates 的连续校正公式计算卡方值 ${ }^{[5]}$, 进行卡方检验, 公式为:

$$
\chi^{2}=\frac{n[|a d-b c|-0.5 n]^{2}}{(a+b)(a+c)(b+d)(c+d)}
$$

式中, $\chi^{2}$ 为卡方检验; $n$ 为总采样点数; $a$ 为一对种共同出现的采样点数; $b 、 c$ 为单个种出现的采样点数; $d$ 为 均不出现的采样点数. 由于 $\chi_{0.05}^{2}(1)=3.841, \chi_{0.05}^{2}(1)=6.635$, 所以 $\chi^{2}>3.841$ 表示种对间联结性显著; $\chi^{2}>$ 6.635 表示种对间联结性极显著. 由于 $\chi^{2}$ 没有负值, 物种间关联的正负性由 $a d-b c$ 来确定, 如 $a d-b c>0$, 则为 正关联, 反之为负关联.

\section{2 结果与分析}

\section{1 浮游植物优势种群落结构特征}

2.1.1 浮游植物组成及优势种经显微镜检测, 在花溪 水库样品中共鉴定出浮游植物 5 门 51 种, 主要包括硅 藻门 ( 17 种, 占比 $33.33 \%$ )、绿藻门 (19 种, 占比 $37.25 \%$ ) 和蓝藻门 ( 8 种, 占比 $15.69 \%$ ), 甲藻门和裸藻 门共 7 种,共占比 $13.72 \%$ (图 2).

如表 1 所示, 根据优势度计算结果 $(Y \geqslant 0.02)$, 共 鉴定出花溪水库 4 个季节浮游植物优势种 4 门 11 种. 优势种的种类和优势度在不同季节均有差异, 春、秋两 季以硅藻门和甲藻门的优势种为主, 秋、冬两季以硅藻

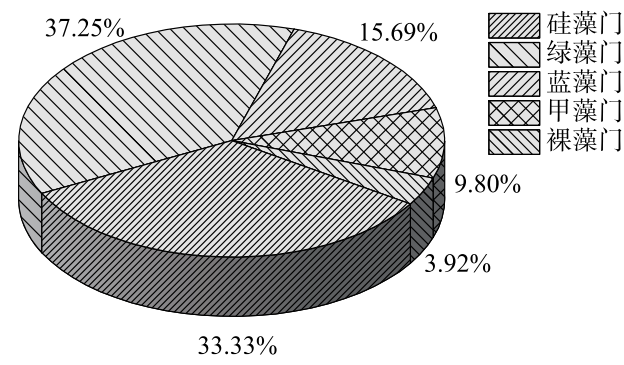

图 2 花溪水库浮游植物物种组成比例

Fig. 2 Composition ratio of phytoplankton species in Huaxi Reservoir 
门和绿藻门的优势种为主, 部分藻种仅在某一季节成为优势种属, 具有较强的季节适应性. 其中硅藻门的尖 针杆藻 (Synedra acusva) 和梅尼小环藻 (Cylotella meneghiniana) 为全年主要优势种, 梅尼小环藻为全年绝对 优势种 $(Y \geqslant 0.1)$, 梅尼小环藻在春季的优势度 $(Y=0.573)$ 最高, 秋季的丰度 $\left(D=1.068 \times 10^{7} \mathrm{cells} / \mathrm{L}\right)$ 最大.

表 1 浮游植物优势种的丰度 $\left(D, \times 10^{6}\right.$ cells $\left./ \mathrm{L}\right)$ 及优势度 $(Y)$

Tab.1 Abundance $\left(D, \times 10^{6}\right.$ cells/L) and dominance $(Y)$ of dominant phytoplankton species

\begin{tabular}{|c|c|c|c|c|c|c|c|c|c|c|}
\hline \multirow{2}{*}{ 编号 } & \multirow{2}{*}{ 门 } & \multirow{2}{*}{ 优势种 } & \multicolumn{2}{|c|}{ 春季 } & \multicolumn{2}{|c|}{ 夏季 } & \multicolumn{2}{|c|}{ 秋季 } & \multicolumn{2}{|c|}{ 冬季 } \\
\hline & & & $D$ & $Y$ & $D$ & $Y$ & $D$ & $Y$ & $D$ & $Y$ \\
\hline 1 & 硅藻门 & $\begin{array}{c}\text { 尖针杆藻 } \\
\text { Synedra acusva }\end{array}$ & 1.01 & 0.110 & 0.88 & 0.233 & 1.99 & 0.024 & 5.34 & 0.045 \\
\hline 2 & & $\begin{array}{c}\text { 颗粒直链藻 } \\
\text { Melosira granulata }\end{array}$ & - & - & - & - & - & - & 7.52 & 0.049 \\
\hline 3 & & $\begin{array}{c}\text { 梅尼小环藻 } \\
\text { Cyclotella meneghiniana }\end{array}$ & 5.25 & 0.573 & 1.44 & 0.438 & 10.68 & 0.299 & 9.94 & 0.121 \\
\hline 4 & & $\begin{array}{c}\text { 菱形藻 } \\
\text { Nitzschia } \text { sp. }\end{array}$ & - & - & - & - & 3.43 & 0.089 & - & - \\
\hline 5 & 绿藻门 & $\begin{array}{c}\text { 四角角星鼓藻 } \\
\text { Staurastrum tetracerum }\end{array}$ & - & - & - & - & 2.11 & 0.029 & - & - \\
\hline 6 & & $\begin{array}{c}\text { 小球藻 } \\
\text { Chlorella sp. }\end{array}$ & - & - & - & - & 3.05 & 0.073 & 4.36 & 0.041 \\
\hline 7 & & $\begin{array}{c}\text { 球衣藻 } \\
\text { Chlamydomonas globosa }\end{array}$ & - & - & 0.23 & 0.042 & - & - & - & - \\
\hline 8 & 蓝澡门 & $\begin{array}{c}\text { 湖泊假鱼腥藻 } \\
\text { Pseudanabaena limnetica }\end{array}$ & - & - & - & - & - & - & 7.59 & 0.049 \\
\hline 9 & & $\begin{array}{c}\text { 色球藻 } \\
\text { Chroococcus sp. }\end{array}$ & - & - & - & - & 2.80 & 0.028 & - & - \\
\hline 10 & & $\begin{array}{c}\text { 湖丝藻 } \\
\text { Limnothrix sp. }\end{array}$ & - & - & 0.19 & 0.027 & - & - & - & - \\
\hline 11 & 甲藻门 & $\begin{array}{c}\text { 倪氏拟多甲藻 } \\
\text { Peridiniopsis niei }\end{array}$ & 1.41 & 0.124 & 0.24 & 0.038 & - & - & - & - \\
\hline
\end{tabular}

“一”表示该藻种在当季末出现.

不同水层浮游植物优势种丰度和优势度的季节变化如图 3 所示, 梅尼小环藻在春、夏、秋季的优势度远 高于其他优势种, 与丰度呈显著正相关. 梅尼小环藻的丰度 $\left(D=5.32 \times 10^{6} \mathrm{cell} / \mathrm{s} / \mathrm{L}\right)$ 在秋季下层水体最高, 优 势度 $(Y=0.60)$ 在春季中层水体最大. 在冬季, 各优势种分布较为不均匀, 其丰度差异较大, 优势度差异较小. 从春季至冬季的季节转变中, 优势种的种群数量逐渐增多, 其丰度也在逐渐增大, 优势度变化趋势逐渐平稳. 2.1.2 优势种丰度 浮游植物优势种丰度的季节变化如图 4 所示, 总体来看, 全年都以硅藻门占主要地位, 其 总丰度呈冬季>秋季>春季>夏季的变化趋势, 各藻门丰度在季节和采样点的分布上则表现出明显的差异性. 硅藻门在 4 个季节的占比均为最高, 每季的占比均超过 $60 \%$, 其夏季占比最大, 为 $78.2 \%$. 绿藻门在秋季的 占比最高, 主要分布在 S1 $\left(1.30 \times 10^{6} \mathrm{cells} / \mathrm{L}\right) 、 \mathrm{~S} 2\left(2.27 \times 10^{6} \mathrm{cells} / \mathrm{L}\right)$ 采样点, 共占秋季绿藻丰度的 $62.6 \%$. 蓝 藻门则在冬季的占比最高, 主要分布在 $\mathrm{S} 1\left(3.50 \times 10^{6} \mathrm{cells} / \mathrm{L}\right) 、 \mathrm{~S} 5\left(4.42 \times 10^{6} \mathrm{cells} / \mathrm{L}\right)$ 采样点, 共占冬季蓝藻 丰度的 $76.9 \%$. 甲藻门的丰度最低, 主要在春季的 $\mathrm{S} 2$ 采样点 $\left(1.36 \times 10^{6} \mathrm{cells} / \mathrm{L}\right)$ 和夏季的 $\mathrm{S} 4$ 采样点 $(6.35 \times$ $\left.10^{4} \mathrm{cells} / \mathrm{L}\right)$ 占比较高, 共占全年甲藻总丰度的 $86.1 \%$ 。

\section{2 浮游植物优势种的生态位}

2.2.1 优势种生态位宽度 浮游植物 4 个季节优势种生态位宽度的变化情况如表 2 所示. 分析了 11 个优势 种的生态位宽度变化范围为 $0.120 \sim 0.814$, 其中 4 个季节均为优势种的梅尼小环藻生态位宽度最大, 冬季的 色球藻生态位宽度最小. 从不同水层 4 个季节优势种生态位宽度变化可以看出 (图 5), 变化情况与混合水 


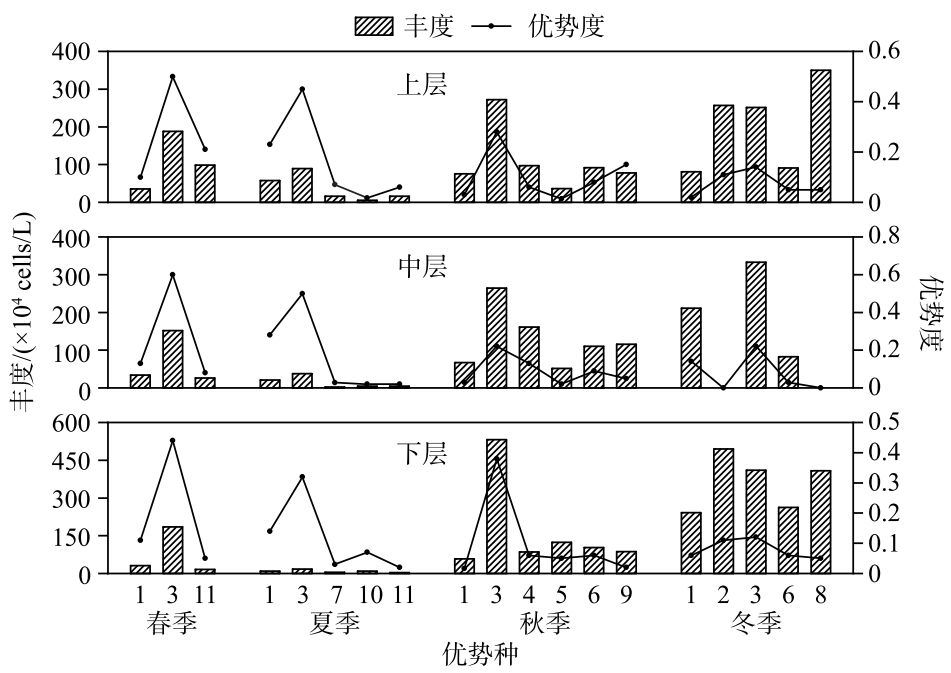

图 3 不同水层浮游植物优势种平均丰度 $(D)$ 及优势度 $(Y)$ 的季节变化 (图中横坐标数字为优势种编号, 对应种名见表 1)

Fig.3 Seasonal variation of abundance $(D)$ and dominance $(Y)$ of dominant phytoplankton species in different water layers
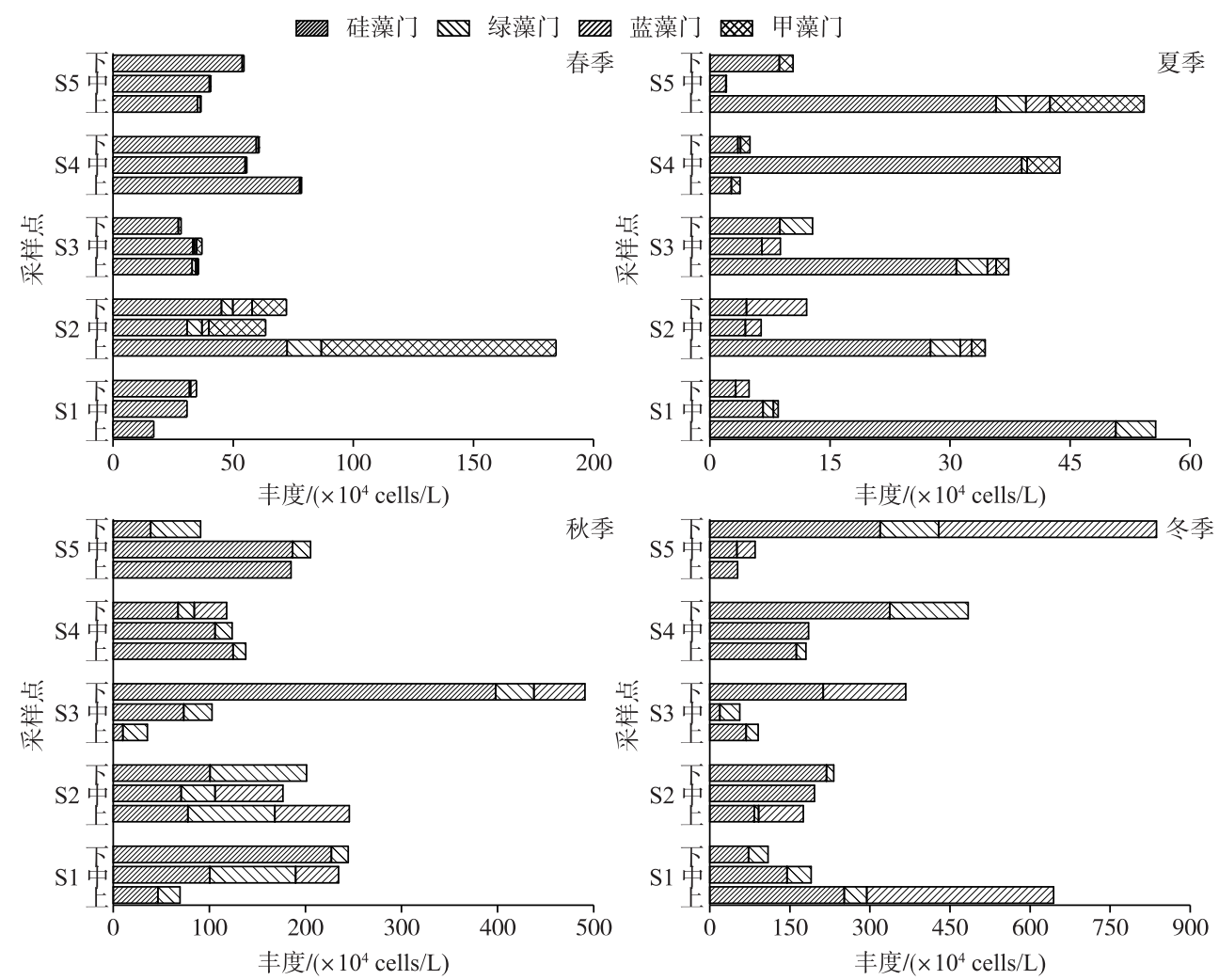

图 4 浮游植物优势类群丰度季节变化

Fig.4 Seasonal variation of abundance of dominant phytoplankton groups 
层计算出的优势种生态位宽度变化一致. 根据各优势种的生态位宽度和生境情况可以将优势种划分为 4 组.

第 1 组: 尖针杆藻和梅尼小环藻. 这两种藻在大多数调查站位都出现且 4 个季节均为优势种, 尖针杆藻 在春、夏两季优势度大于 0.1 , 而梅尼小环藻优势度全年都大于 0.1 , 梅尼小环藻在春、秋、冬季生态位宽度大 于 0.5 , 尖针杆藻在冬季生态位宽度大于 0.5 . 这一组是体现整个藻类群落结构和水环境状况的重要指标.

第 2 组: 菱形藻、小球藻和倪氏拟多甲藻. 菱形藻主要在秋季各水层均匀分布, 且生态位宽度大于 0.5 , 小球藻出现在秋、冬季, 且丰度在持续增加, 兒氏拟多甲藻出现在春、夏季, 丰度在持续减小, 在秋季退出优 势种群. 这一组受环境因子和季节变化影响,呈现明显的生境适应性变化.

第 3 组: 湖泊假鱼腥藻、色球藻和湖丝藻. 这一组藻类作为对生境适应性较强的蓝藻门, 存在于多种类 型水体中, 常作为水体污染状况和湖泊营养型评价的指示种.

第 4 组: 颗粒直链藻、四角角星鼓藻、球衣藻. 这一组藻类优势度和生态位宽度都较小, 到合适的季节常 作为伴生优势种出现.

表 2 浮游植物优势种的生态位宽度 $\left(B_{i}\right)$

Tab.2 Niche width of dominant phytoplankton species $\left(B_{i}\right)$

\begin{tabular}{|c|c|c|c|c|}
\hline 优势种 & 春季 & 夏季 & 秋季 & 冬季 \\
\hline 尖针杆藻 & 0.488 & 0.451 & 0.365 & 0.507 \\
\hline 颗粒直链藻 & - & - & - & 0.371 \\
\hline 梅尼小环藻 & 0.814 & 0.489 & 0.523 & 0.642 \\
\hline 菱形藻 & - & - & 0.598 & - \\
\hline 四角角星鼓藻 & - & - & 0.310 & - \\
\hline 小球藻 & - & - & 0.603 & 0.379 \\
\hline 球衣藻 & - & 0.399 & - & - \\
\hline 湖泊假鱼腥藻 & - & - & - & 0.120 \\
\hline 色球藻 & - & - & 0.308 & - \\
\hline 湖丝藻 & - & 0.298 & - & - \\
\hline 倪氏拟多甲藻 & 0.129 & 0.225 & - & - \\
\hline
\end{tabular}

“_”表示该藻种在当季未出现.

2.2.2 优势种生态位重叠 为了更准确地确定浮游植物优势种的生态响应, 本文利用水库混合水层整体计 算, 结合生态位宽度分析了不同季节下生态位重叠 $\left(\Delta O_{i k}\right)$ 和生态响应速率 $R$, 如表 3 所示.

表 3 浮游植物优势种生态位重叠 $\left(\Delta O_{i k}\right)$ 和生态响应速率 $(R)$

Tab.3 Niche overlap $\left(\Delta O_{i k}\right)$ and ecological response rate $(R)$ of dominant phytoplankton species

\begin{tabular}{|c|c|c|c|c|c|c|c|c|}
\hline \multirow{2}{*}{ 优势种 } & \multicolumn{2}{|c|}{ 春季 } & \multicolumn{2}{|c|}{ 夏季 } & \multicolumn{2}{|c|}{ 秋季 } & \multicolumn{2}{|c|}{ 冬季 } \\
\hline & $\Delta O_{i k}$ & $R$ & $\Delta O_{i k}$ & $R$ & $\Delta O_{i k}$ & $R$ & $\Delta O_{i k}$ & $R$ \\
\hline 尖针杆藻 & 1.002 & 0.487 & 0.079 & 5.712 & -1.364 & -0.267 & -1.855 & -0.273 \\
\hline 颗粒直链藻 & - & - & - & - & - & - & -0.56 & -0.663 \\
\hline 梅尼小环藻 & 0.06 & 13.52 & -0.392 & -1.249 & -1.383 & -0.379 & -0.369 & -1.74 \\
\hline 菱形藻 & - & - & - & - & -2.694 & -0.222 & - & - \\
\hline 四角角星鼓藻 & - & - & - & - & -3.658 & -0.085 & - & - \\
\hline 小球藻 & - & - & - & - & -1.15 & -0.525 & -0.55 & -0.689 \\
\hline 球衣藻 & - & - & -0.821 & -0.486 & - & - & - & - \\
\hline 湖泊假鱼腥藻 & - & - & - & - & - & - & -1.774 & -0.068 \\
\hline 色球藻 & - & - & - & - & -2.374 & -0.13 & - & - \\
\hline 湖丝藻 & - & - & -3.317 & -0.09 & - & - & - & - \\
\hline 倪氏拟多甲藻 & 0.546 & 0.236 & -1.216 & -0.185 & - & - & - & - \\
\hline
\end{tabular}

“一”表示该藻种在当季未出现. 

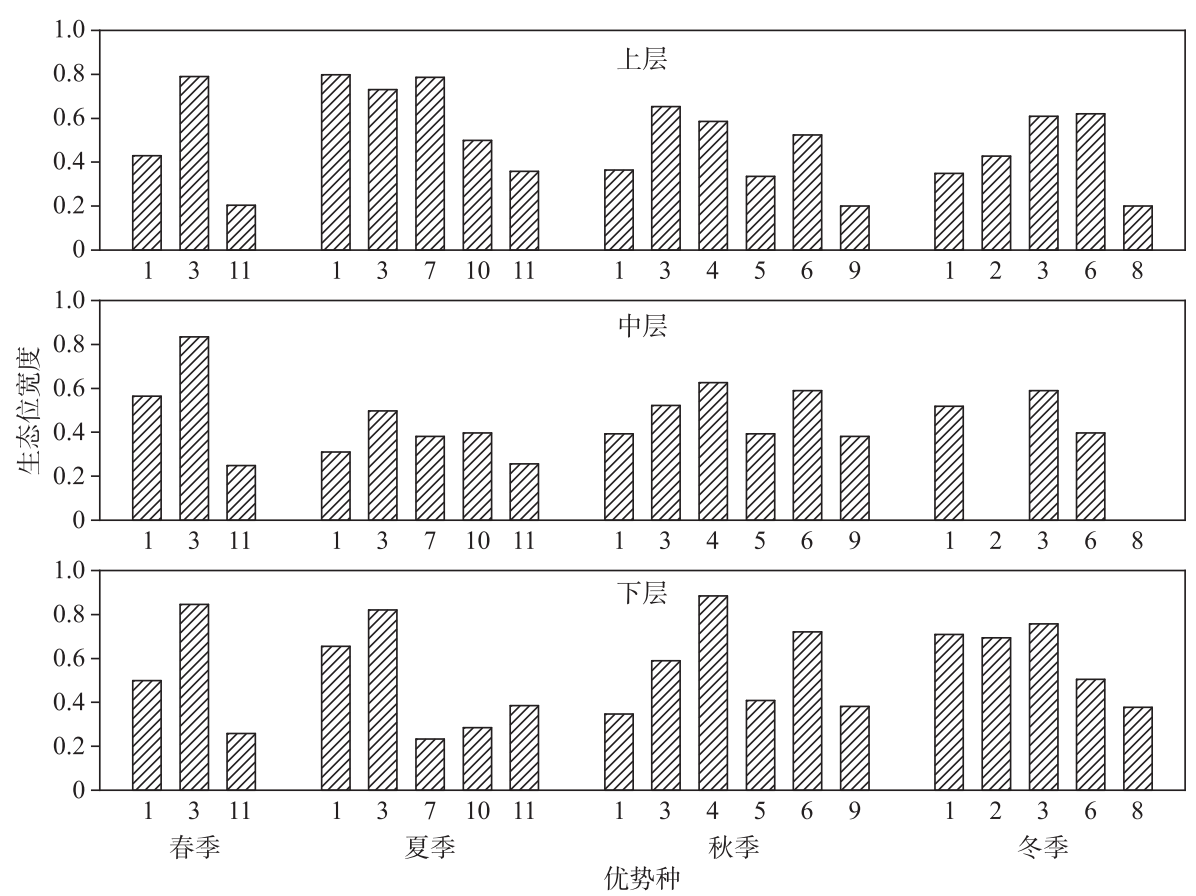

图 5 不同水层浮游植物优势种生态位宽度 $\left(B_{i}\right)$ 的季节变化

(图中横坐标数字为优势种编号, 对应种名见表 1)

Fig.5 Seasonal variation of niche width $\left(B_{i}\right)$ of dominant phytoplankton species in different water layers

11 个浮游植物优势种的生态位重叠值 $O_{i k}$ 变化范围为 $0.101 \sim 0.936$, 季节性差异较大. 在春季, 各优势种 的生态位重叠 $\Delta O_{i k}$ 均为正值, 且梅尼小环藻生态响应速率 $R$ 值最大, 为 13.52 , 说明浮游植物群落结构呈多 样性发展阶段. 在夏季, 出现了生态位重叠的最大值, 尖针杆藻一梅尼小环藻 ( 0.936$)$, 说明在夏季是适合多 种藻类共存的生境条件. 在秋季,生态位重叠值 $O_{i k}$ 变化范围为 $0.184 \sim 0.752, R$ 值持续减小,物种多样性的稳 定程度处于缓慢的衰退状态. 在冬季, 尖针杆藻一湖泊假鱼腥藻的生态位重叠值最小, 仅为 0.101 , 小环藻的 $R$ 值也达到了最小值 $(-1.740)$, 说明由季节变化所引起的藻类空间分布频率变化较大, 使得藻种间重叠度 较低,群落结构正在无规律改变.

\section{3 浮游植物优势种的种间联结性}

由表 4 可知, 花溪水库全年浮游植物物种间总体关联性的方差比率 $V R$ 值均大于 1 , 表明在独立零假设 条件下, 藻类群落间呈正关联性, 通过统计量 $W$ 值检验, 其值均大于 $\chi^{2}$ 的临界值范围, 表明关联性显著.

表 4 浮游植物优势种的总体关联性

Tab.4 Overall association of dominant phytoplankton species

\begin{tabular}{|c|c|c|c|c|c|}
\hline 季节 & $\begin{array}{c}\text { 方差比率 } \\
V R\end{array}$ & $\begin{array}{c}\text { 检验统计量 } \\
W\end{array}$ & $\mathrm{~d} f$ & $\begin{array}{c}\chi^{2} \text { 的临界值 } \\
{\left[\chi_{0.95 N}^{2}(\mathrm{~d} f), \chi_{0.05 N}^{2}(\mathrm{~d} f)\right]}\end{array}$ & 校验结果 \\
\hline 春季 & 5 & 75 & 2 & {$[0.103,5.991]$} & 显著正关联 \\
\hline 夏季 & 2.541 & 38.12 & 4 & {$[0.711,9.488]$} & 显著正关联 \\
\hline 秋季 & 1.533 & 22.99 & 5 & {$[1.145,11.07]$} & 显著正关联 \\
\hline 冬季 & 2.786 & 41.79 & 4 & {$[0.711,9.488]$} & 显著正关联 \\
\hline
\end{tabular}

种间联结性结果如图 6 所示, 在 38 个种对内, 联结性不显著 $\left(\chi^{2}<3.841(P>0.05)\right)$ 的种对有 29 对, 联 
结性显著的有 9 对, 关联性的显著率为 $23.7 \%$. 这 9 对均为正联结显著 $\left(3.841 \leqslant \chi^{2} \leqslant 6.635(0.01 \leqslant P \leqslant\right.$ $0.05), a d<b c)$, 其中 4 对出现在夏季, 4 对出现在秋季, 1 对出现在冬季, 以梅尼小环藻的种对为主. 在秋 季, 梅尼小环藻与尖针杆藻的种对间的卡方检验值 $\left(\chi^{2}=5.0\right)$ 最大, 显著性最高, 同样在秋季, 梅尼小环藻与 菱形藻的种间的卡方检验值 $\left(\chi^{2}=4.0\right)$ 最小, 显著性较低.

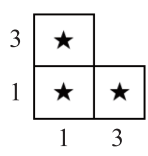

春季
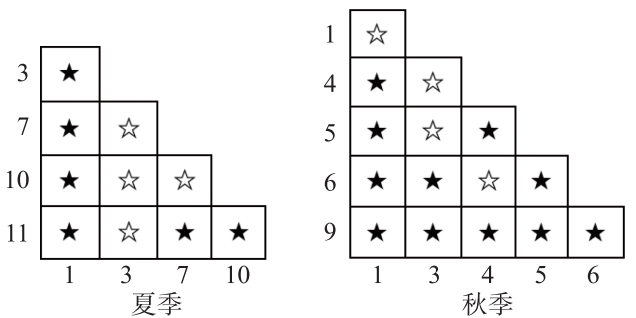

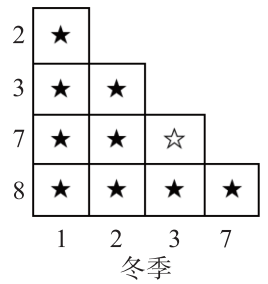

图 6 浮游植物优势种间 $\chi^{2}$ 检验半矩阵

$\left(\star, \chi^{2}<3.841(P>0.05) ; \bullet, \chi^{2}>6.635(P<0.01), a d<b c ;\right.$ 计, $3.841 \leqslant \chi^{2} \leqslant 6.635(0.01 \leqslant P \leqslant 0.05)$, $a d<b c ; \bigcirc, 3.841 \leqslant \chi^{2} \leqslant 6.635(0.01 \leqslant P \leqslant 0.05), a d>b c$; 图中横坐标数字为优势种编号, 对应种名见表 1)

Fig.6 Semi-matrix of $\chi^{2}$ test for dominant phytoplankton species

\section{3 讨论}

\section{1 优势种生态位宽度与重叠值}

生态位宽度反映了一个物种利用环境中各种资源的能力, 也是物种适应环境能力的一种体现 ${ }^{[20]}$. 依据 物种所占有空间资源能力的强弱和分布范围的广泛程度情况 ${ }^{[21]}$, 根据其大小可分为狭生态位和广生态 位 ${ }^{[19]}$. 生态位越宽, 表示物种对环境中各种资源的利用能力越强, 其在环境中的竞争能力就越强, 即为广布 种或是泛化种, 反之则为特化种. 梅尼小环藻和尖针杆藻在 4 个季节中均为优势种, 且在 5 个采样点的上、 中、下层皆有分布, 对环境的适应能力和所占空间资源能力都远超其他优势种, 秋季的菱形藻 $\left(B_{i}=0.598\right)$ 和小球藻 $\left(B_{i}=0.603\right)$ 在 5 个采样点的上、中、下层皆有分布 (图 5 ), 分布的范围较广, 生态位宽度都大于 0.5 (表 2), 都可划归为广生态位种类. 而生态位值较小的种类主要是春季的倪氏拟多甲藻 $\left(B_{i}=0.129\right)$ 和冬季 的湖泊假鱼腥藻 $\left(B_{i}=0.120\right)$ (表 2$)$, 其对环境条件依赖性较大, 只在合适的温度和营养条件下才能大量繁 殖, 这类可划归为狭生态位种类. 生态位宽度的大小反映了物种的分布和数量, 分布广、占据资源位点较多 的优势种往往生态位宽度值都较大,这与徐春燕等 ${ }^{[7]}$ 的研究结果一致.

然而, 在复杂的水环境中, 广生态位藻种的活动情况是体现整个藻类群落结构和水环境状况的重要指 标, 因此可以用来判断出水库水质的本质特征 ${ }^{[22]}$. 梅尼小环藻、尖针杆藻、菱形藻和小球藻皆为富营养化指 示种, 其中梅尼小环藻、尖针杆藻和菱形藻常出现在有机物浓度高且透明度较高的水体 ${ }^{[23]}$, 这与 Wang 等 ${ }^{[10]}$ 于 2015 年在沉积物中发现有机物含量过高和花溪水库透明度较高 (表 5) 的结果相吻合, 表明了花溪水库水 质属于 $\beta$-污染型水体. 这一结论与王翠红等 ${ }^{[24]}$ 和孟东平等 ${ }^{[25]}$ 得出的以污染带种生态位宽度指示水体污染 程度的结论一致. 另一类生态位较小的藻类, 由于生境特化常作为水域的指示种, 春季的倪氏拟多甲藻生态 位宽度较低, 可能是花溪水库生态调节后对藻类群落结构干扰较大所致, 而冬季的湖泊假鱼腥藻丰度 $\left(7.59 \times 10^{6} \mathrm{cells} / \mathrm{L}\right.$ ) 在当季优势种中占比较高 (表 1), 但由于分布极不均匀 (图 3), 使得湖泊假鱼腥藻的生态 位宽度 $\left(B_{i}=0.120\right)$ 较小 (表 2 ), 可能是冬季温度和氮磷比 (表 5 ) 变化较大所致, 通过对汪志聪等 ${ }^{[8]}$ 利用浮 游植物生态位模型在巢湖鱼腥藻水华预测方面应用的分析表明,等来年回温后,一定气象条件下可能会出 现湖泊假鱼腥藻水华的风险.

生态位重叠指数 $O_{i k}$ 是物种间对资源利用的相似性测度, 在相同生境下, 两个物种之间利用资源或栖息 环境相似的情况下,会导致生态位重叠情况发生 ${ }^{[26]}$. 同时,生态位重叠是物种间竞争的必要非充分条件 ${ }^{[27]}$. 主要表现在物种对共享资源的利用的需求, 当资源贵乏时, 生态位重叠的物种容易产生种间竞争, 反之, 就 不一定会产生种间竞争 ${ }^{[28]}$. 本文研究了不同季节下优势种间的生态位重叠情况, 在夏季, 尖针杆藻与梅尼 
小环藻生态位重叠值的最大值为 0.936 , 同样, 在春、秋和冬季中, 尖针杆藻和梅尼小环藻的生态位重叠值都 处于较高水平, 这可能与它们的营养利用特征及生活型相关, 尖针杆藻和梅尼小环藻都属于硅藻门, 外界的 生存环境相似, 而花溪水库水体营养化程度高, 且属于喀斯特高原水库, 硅元素比较充足 ${ }^{[29]}$, 因此在共用资 源的情况下, 生态位重叠显著. 在夏季, 部分生态位宽度较窄的物种与生态位较宽的物种间的重叠值较大, 如球衣藻与梅尼小环藻、倪氏拟多甲藻与尖针杆藻等, 球衣藻和倪氏拟多甲藻的生态位宽度都较低, 其物种 丰度和优势度值都远低于梅尼小环藻和尖针杆澡, 但它们的生态位重叠值较高, 这可能是因为尽管它们的 样点重合度高, 但资源利用方式不同, 即使对生境资源有共同需求,但表现为利用方式互补而非种间竞争, 物种间趋向于稳定共存 ${ }^{[30]}$. 这与戴冬旭等 ${ }^{[31]}$ 和吴佳梦等 ${ }^{[32]}$ 的研究结果相吻合. 在冬季, 优势种尖针杆藻与 湖泊假鱼腥藻的重叠值最小, 仅为 0.101 , 尖针杆藻主要分布在水体中层, 湖泊假鱼腥藻主要分布在水体的 上、下两层 (图 5), 说明尖针杆藻和湖泊假鱼腥藻基本是交叉分布水体中,因而两个物种之间不会因为争夺 资源而产生种间竞争.

由生态位重叠值 $\Delta O_{i k}$ 所反映的情况可以看出, 仅春季 3 种优势种和夏季的尖针杆藻为发展型, 梅尼小 环藻和尖针杆藻适于春季生长, 梅尼小环藻从夏季到冬季逐渐转变为衰退型, 倪氏拟多甲藻在秋、冬两季则 不再为优势种, 随着春季到冬季的转变中, 优势种逐渐增多, 从夏季开始优势种都逐渐转变为衰退型. 这可 能是由于在春季浮游植物群落优势种仅有 3 种, 优势种间相互竞争压力较小, 而在其他季节随着优势种数 量增多, 影响其对资源的利用, 导致种间对资源利用的竞争压力增大 ${ }^{[20]}$. 冬季的优势藻种都呈衰退型趋势, 造成该现象的原因可能与气候变化导致的水温和溶解氧浓度的减小 (表 5) 或其他人为干扰有关, 此外, 随着 季节性的变化,不同藻类优势种的形成均可能造成群落结构的改变, 从而影响群落的演替趋势 ${ }^{[33]}$.

表 5 花溪水库各季节水体理化指标均值

Tab.5 Average values of physical and chemical indexes of Huaxi Reservoir in each season

\begin{tabular}{ccccccccccc}
\hline 季节 & $\begin{array}{c}\mathrm{WT} / \\
{ }^{\circ} \mathrm{C}\end{array}$ & $\begin{array}{c}\mathrm{DO} / \\
(\mathrm{mg} / \mathrm{L})\end{array}$ & $\mathrm{pH}$ & $\begin{array}{c}\mathrm{SD} / \\
\mathrm{m}\end{array}$ & $\begin{array}{c}\mathrm{TN} / \\
(\mathrm{mg} / \mathrm{L})\end{array}$ & $\begin{array}{c}\mathrm{DIN} / \\
(\mathrm{mg} / \mathrm{L})\end{array}$ & $\begin{array}{c}\mathrm{TP} / \\
(\mathrm{mg} / \mathrm{L})\end{array}$ & $\begin{array}{c}\mathrm{PO}_{4}^{3-}-\mathrm{P} / \\
(\mathrm{mg} / \mathrm{L})\end{array}$ & $\begin{array}{c}\mathrm{COD} \\
(\mathrm{mg} / \mathrm{L})\end{array}$ & $\begin{array}{c}\mathrm{Chl} . a / \\
\left(\mathrm{mg} / \mathrm{m}^{3}\right)\end{array}$ \\
\hline 春季 & 17.15 & 10.98 & 7.84 & 1.86 & 2.54 & 2.18 & 0.01 & 0.01 & 2.10 & 5.44 \\
夏季 & 22.48 & 10.26 & 8.27 & 2.26 & 2.97 & 3.12 & 0.06 & 0.01 & 2.54 & 2.21 \\
秋季 & 19.13 & 8.47 & 8.14 & 2.06 & 2.25 & 1.58 & 0.05 & 0.01 & 1.94 & 4.20 \\
冬季 & 9.29 & 5.92 & 8.31 & 2.48 & 1.31 & 1.82 & 0.01 & 0.01 & 1.57 & 2.83 \\
\hline
\end{tabular}

\section{2 优势种种间联结性}

种间联结表示各藻种间在共同生境中的关联程度, 在本文研究中利用方差比率求出各季节 $V R$ 值显示, 其值都大于 1 , 表明生态系统结构相对成熟, 有正向演替的趋势 ${ }^{[27]}$. 调查的 11 种浮游植物优势种中 38 个种 对内, 有高达 29 个种对为不显著联结, 即这些种对的优势种相互独立. 这可能是由于这些物种在资源和空 间上的相互依赖程度低,生活习性上存在一定的差异,从而导致联结程度较低.

基于卡方检验,分析得出其余 9 个种对全部为正联结, 在 9 个正联结的种对内, 又以梅尼小环藻的种对 为主, 与另一单季节出现的优势种呈正联结, 说明花溪水库的浮游植物群落结构比较稳定, 形成以梅尼小环 藻为主导地位, 与另一优势澡种共同占有同一食物、营养成分和空间的稳定演替模式 ${ }^{[34]}$. 这可能与花溪水 库 4 个季节都以硅藻为主要优势种有关, 空间分布均匀, 而另一优势种都以单季节出现, 且出现在不同的空 间范围内, 不存在多个优势藻种间为竞争关系的情况, 从而使得出现联结性的种对之间都是正联结. 这与张 先平等 ${ }^{[35]}$ 所提出的取样面积过大、物种间相互竞争数量少、种间关系多为正联结的性的结论相吻合.

通过分析正联结的物种对的分布情况得知, 在春季, 优势种少且联结性不显著, 可能是由生态调控引起 的藻类群落结构紊乱所致, 经过几个月水生态系统的自我修复 ${ }^{[36]}$, 夏季和秋季分别都出现了 4 对正联结的 物种对 (图 6), 表明藻类群落结构已恢复到了稳定状态, 到冬季时, 正联结的物种对减少, 仅出现 1 对, 且出 现了特化种, 进一步表明水环境变化较大, 此时多需观察水质变化情况, 有问题则需及时采取适当的应对措 施, 从而达到预防来年春季水华再次发生的目的. 


\section{4 结论}

1) 花溪水库全年共鉴定出浮游植物 5 门 51 种, 4 个季节优势种 4 门 11 种,其中尖针杆藻和梅尼小环藻 为全年优势种. 调控后的水生态系统经自我修复后, 优势种数量增多, 种间联系更紧密, 生态指示作用更加 明显准确.

2) 花溪水库广生态位中的梅尼小环藻和尖针杆藻所指示的水质状态与调查结果一致, 因此利用生态位 宽度大的优势种群对水质指示有可靠的生态学意义. 生态位重叠值的大小可以反映优势藻种的演替模式, 从而反映水质的变化情况.

3 ) 根据种间联结结果显示: 花溪水库浮游植物优势种间总体上呈显著正相关. 夏、秋季的植物群落结构 比较稳定,冬季群落结构受外界环境因子的影响,使得群落结构处于不稳定的发展阶段.

\section{5 参考文献}

[ 1 ] Zhang X, Yi QT, Xie K et al. Nutrient kinetics of dominant species of phytoplankton in the artificial lakes formed from land subsidence by mining activities in the Huainan coalmine subsidence areas. J Lake Sci, 2018, 30(3) : 713-722. DOI: 10.18307/2018.0313. [张金金, 易齐涛, 谢凯等. 淮南采煤塌陷湖泊浮游植物优势种的营养动力学. 湖泊科学, $2018, \mathbf{3 0}(3): 713-722$.

[ 2 ] Wang ZF, Zhang W, Yang L et al. Characteristics of phytoplankton community and its relationship with environmental factors in different regions of Yilong Lake, Yunnan Province, China. Environmental Science, 2019, 40 ( 5 ) : 2249-2257. DOI : 10.13227/j.hjkx.201810157. [王振方, 张玮, 杨丽等. 异龙湖不同湖区浮游植物群落特征及其与环境因子的 关系. 环境科学, 2019, 40(5): 2249-2257.]

[ 3 ] Li QH. Characteristics and evaluation ofeutrophication in Guizhou plateau reservoirs. Journal of Guizhou Normal University: Natural Sciences, 2018, 36(2) : 1-8. [李秋华. 贵州高原水库富营养化特征及评价. 贵州师范大学学报: 自然科学 版, 2018, 36(2): 1-8.]

[ 4 ] Qian KM, Chen YW, Song XL. Long-term development of phytoplankton dominant species related to eutrophication in Lake Taihu. Ecological Science, 2008, 27(2): 65-70. [ 钱奎梅, 陈宇炜, 宋晓兰. 太湖浮游植物优势种长期演化与 富营养化进程的关系. 生态科学, 2008, 27(2): 65-70.]

[ 5 ] Liu Y, Zheng YY, Ao YY. Niche and interspecific association of dominant bryophytes on different substrates. Acta Ecologica Sinica, 2019, 39(1) : 286-293. DOI: 10.5846/stxb201711162042. [刘艳, 郑越月, 敖艳艳. 不同生长基质的苔藓 植物优势种生态位与种间联结. 生态学报, 2019, 39(1): 286-293.]

[6] Xia T, Chen J, Cao FY et al. Niche analysis of phytoplankton in an urban river connected with the Yangtze River, Zhenjiang, China. Resources and Environment in the Yangtze Basin, 2014, 23(3) : 344-350 [夏霆, 陈静, 曹方意等. 镇江通 江城市河道浮游植物优势种群生态位分析. 长江流域资源与环境, 2014, 23(3): 344-350]

[ 7 ] Xu CY, Yu QJ, Xu FJ et al. Niche analysis of phytoplankton's dominant species in Dianshan Lake of East China. Chinese Journal of Applied Ecology, 2012, 23(9) : 2550-2558. DOI: 10.13287/j.1001-9332.2012.0358. [徐春燕, 俞秋佳, 徐 凤洁等. 淀山湖浮游植物优势种生态位. 应用生态学报, 2012, 23(9): 2550-2558.]

[ 8 ] Wang ZC, Wu WJ, Zuo M et al. Niche analysis of phytoplankton community in Lake Chaohu. Resources and Environment in the Yangtze Basin, 2010, 19(6) : 685-691. [汪志聪, 吴卫菊, 左明等. 巢湖浮游植物群落生态位的研究. 长江流 域资源与环境, $2010,19(6): 685-691$.

[ 9 ] Wang X, Li LQ, Zheng BH et al. Composition and influential factors of algal function groups in Dongting Lake. China Environmental Science, 2016, 36(12): 3766-3776. [汪星, 李利强, 郑丙辉等. 洞庭湖浮游藻类功能群的组成特征及 其影响因素研究. 中国环境科学, 2016, 36(12) : 3766-3776.]

[10] Wang L, Han MS, Li QH et al. Studies on polycyclic aromatic hydrocarbons in two sediment cores from the Huaxi reservoir, China: Assessment of levels, sources, and ecological risk. Environmental Forensics, 2018, 19(1) : 50-58. DOI: 10. 1080/15275922.2017.1408158.

[11] Ma XY, Li QH, Chen Q et al. Variation characteristics and influencing factors of the structure of a phytoplankton community after an ecological regulation in Huaxi Reservoir, Guizhou Province. Research of Environmental Sciences, 2020, 33 (3) : 589-598. [马欣洋, 李秋华, 陈倩等. 生态调控后贵州花溪水库浮游植物群落结构的变化特征及影响因素. 
环境科学研究, 2020, 33(3): 589-598.]

[12] Jing XC, Tu QY eds. Standards for investigation of lake eutrophication: Second edition. Beijing: China Environmental Press, 1990: 107-134. [ 金相灿, 屠清瑛. 湖泊富营养化调查规范: 第二版. 北京: 中国环境科学出版社, 1990: 107-134.]

[13] Hu HY, Wei YX eds. Freshwater algae in China-system, classification and ecology. Beijing: Science Press, 2006: 51020. [胡鸿钧, 魏印心. 中国淡水藻类——系统、分类及生态. 北京: 科学出版社, 2006: 5-1020.]

[14] Deng J ed. Atlas of common algae in inland waters of China. Wuhan: Yangtze Press, 2012: 1-241. [邓坚. 中国内陆水域 常见藻类图谱. 武汉: 长江出版社, 2012: 1-241.]

[15] Lin SJ, He LJ, Hunag PS et al. Comparison and improvement on the extraction method for chlorophyll a in phytoplankton. Ecologic Science, 2005, 24(1): 9-11. [ 林少君, 贺立静, 黄沛生等. 浮游植物中叶绿素 a 提取方法的比较与改进. 生态科学, 2005, 24(1): 9-11.]

[16] Sun J, Liu DY, Ning XR et al. Phytoplankton in the Prydz Bay and the adjacent Indian sector of the southern ocean during the Austral summer 2001/2002. Oceanologia et Limnologia Sinica, 2003, 34(5): 519-532. [孙军, 刘东艳, 宁修仁等. 2001/2002 年夏季南极普里兹湾及其邻近海域的浮游植物. 海洋与湖沼, 2003, 34( 5) : 519-532.]

[17] Wan L, Zhu W. Study on phytoplankton predominant species niche in stagnation water of Suzhou City. Ecological Science, 2009, 28(2) : 152-157. [万蕾, 朱伟. 苏州城市河道滞流水体浮游植物常见属生态位研究. 生态科学, 2009,28 (2) : 152-157.]

[18] Liang M, Jiang Q, Sun LY et al. Spatial niches of dominant macro-zooplankton and meso-zooplankton species in the coastal area of Caofeidian. Ecology and Environmental Sciences, 2018, 27(7) : 1241-1250. [梁沝, 姜倩, 孙丽艳等. 曹妃甸近 岸海域大、中型浮游动物优势种空间生态位研究. 生态环境学报, 2018, 27(7)：1241-1250.]

[19] Liu H, Guo PJ, Chen ZJ et al. Niche and interspecific association of main crustaceans in the nearshore waters of Zhoushan. Acta Oceanologica Sinica, 2019, 41(4) : 83-93. [刘惠, 郭朋军, 陈洲杰等. 舟山近岸海域主要甲壳类的生态位及其 与种间联结性. 海洋学报: 中文版, 2019, 41(4) : 83-93.]

[20] Li X, Li JR, Li CY. Ecological niche analysis of dominant phytoplankton species in Wuliangsuhai Lake, Inner Mongolia. Journal of Hydroecology, 2017, 38(6) : 40-47. DOI: 10.15928/j.1674-3075.2017.06.006. [李兴, 李建茹, 李畅游. 内 蒙古乌梁素海浮游植物优势种的生态位分析. 水生态学杂志, 2017, 38(6) : 40-47.]

[21] Jiang WX, Fu XC, Tang T et al. Community structure and niche of macroinvertebrates in the Xiangxi River in Hubei, China. Chinese Journal of Applied \& Environmental Biology, 2009, 15(3):337-341. [蒋万祥, 傅小城, 唐涛等. 香溪河水 系大型底栖动物的群落结构及生态位. 应用与环境生物学报, 2009, 15(3): 337-341.]

[22] Yang WH, Shen H, Zhou ML et al. Seasonal variation analysis of the niche and interspecific association with respect to the dominant phytoplankton species in Nanhai Lake. China Environmental Science, 2020, 40(1): 383-391. [杨文焕, 申涵, 周明利等. 包头南海湖浮游植物优势种生态位及种间联结性季节分析. 中国环境科学, 2020, 40(1): 383-391.]

[23] Kuang QJ, Ma PM, Hu ZY et al. Study on the evaluation and treatment of lake eutrophication by means of algae biology. Journal of Safety and Environment, 2005, 5(2): 87-91. [况琪军, 马沛明, 胡征宇等. 湖泊富营养化的藻类生物学 评价与治理研究进展. 安全与环境学报, 2005, 5(2): 87-91.]

[24] Wang CH, Zhang JT. Niche analysis of diatoms inFenhe River and Fenhe Reservoir. Chinese Journal of Ecology, 2004,23 (3) : 58-62. [王翠红, 张金屯. 汾河水库及河道中优势硅藻生态位的研究. 生态学杂志, 2004, 23(3): 58-62.]

[25] Meng DP, Wang CH, Xin XY et al. Niche analysis of algae species in Taiyuan segment of Fenhe River. Environmental Science \& Technology, 2006, 29 (10) : 95-97, 120-121. [孟东平, 王翠红, 辛晓芸等. 汾河太原段水体浮游藻类生态位 的研究. 环境科学与技术, 2006, 29(10): 95-97, 120-121.]

[26] Liu SY, Yu XX, Chen LH. Interspecific association and niche research of natural forest in Beijing Mountainous Area. Journal of Northwest Forestry University, 2009, 24(5): 26-30,81. [刘淑燕, 余新晓, 陈丽华. 北京山区天然林乔木树种 种间联结与生态位研究. 西北林学院学报, 2009, 24(5): 26-30,81.]

[27] Deng XY, Liu JG, Guo PJ et al. Niche and interspecific association of major nekton in Xiao Yangshan adjacent waters. Acta Oceanologica Sinica, 2018, 40(1): 96-105. [邓小艳, 刘建国, 郭朋军等. 小洋山邻近海域主要游泳动物生态位 及种间联结性. 海洋学报: 中文版, 2018, 40(1) : 96-105.]

[28] Liao BW, Li M, Zheng SF et al. Niches of several mangrove species in Dongzhai Harbor of Hainan Island. Chinese Journal of Applied Ecology, 2005, 16(3) : 403-407. [廖宝文, 李玫, 郑松发等. 海南岛东寨港几种红树植物种间生态位研 
究. 应用生态学报, 2005, 16(3): 403-407.]

[29] Hu R, Lan YQ, Xiao LJ et al. The concepts, classification and application of freshwater phytoplankton functional groups. $J$ Lake Sci , 2015, 27 (1) : 11-23. DOI: 10.18307/2015.0102. [胡韧, 蓝于倩, 肖利娟等. 淡水浮游植物功能群的概 念、划分方法和应用. 湖泊科学, 2015, 27(1): 11-23.]

[ 30] Qiu JJ, Wang YX, Li TJ et al. Study on the niche and differentiation of major nekton species in the Zhoushan Changbai sea area. Acta Ecologica Sinica, 2018, 38(18) : 6759-6767. DOI: 10.5846/stxb201803300680. [求锦津, 王咏雪, 李铁军 等. 舟山长白海域主要游泳动物生态位及其分化研究. 生态学报, 2018, 38(18): 6759-6767.]

[31] Dai DX, Yu CG, Liu H et al. Niche and interspecific association of major nekton in the sea area to the east of the Nanji Islands. Chinese Journal of Applied Ecology, 2019, 30(12) : 4249-4258. DOI: 10.13287/j.1001-9332.201912.033. [戴 冬旭, 俞存根, 刘惠等. 南鹿列岛东侧海域主要游泳动物生态位及种间联结性. 应用生态学报, 2019, 30(12): 4249-4258.

[32] Wu JM, Xu NN, Zhang WJ et al. Seasonal analysis of the niche and interspecific association of dominant species of phytoplankton in the Dinghai Moat, Zhoushan City. J Lake Sci, 2019, 31(2) : 429-439. DOI: 10.18307/2019.0212. [吴佳 梦, 徐娜娜, 张文珺等. 浙江舟山定海护城河浮游植物优势种生态位与种间联结性季节性分析. 湖泊科学, 2019, 31(2) : 429-439.]

[33] Li CN, Shui YY, Tian K et al. A study of niche and interspecific association and functional group of major nekton in the spring of Wenzhou Bay. Acta Ecologica Sinica, 2017, 37(16) : 5522-5530. DOI: 10.5846/stxb201605301035. [李超男, 水玉跃, 田阔等. 温州湾春季主要游泳动物生态位与种间联结性. 生态学报, 2017, 37(16) : 5522-5530.]

[34] Zhang YF, Ren Z, Deng RY et al. Species diversity and inter-specific association between vertical layers in coastal natural plant communities. Guangxi Sciences, 2019, 26(3) : 324-334. [张艺帆, 任哲, 邓荣艳等. 滨海自然植物群落物种多 样性及种间垂直联结性. 广西科学, 2019, 26(3) : 324-334.]

[35] Zhang XP, Wang MB, Zhang WF et al. Interspecific relationships among woody plants of forest communities in Pangquangou National Nature Reserve at Mt. Guandi, Shanxi, China. Bulletin of Botanical Research, 2007, 27 (3) : 350355,371 . [张先平, 王孟本, 张伟锋等. 庞泉沟国家自然保护区森林群落木本植物种间关系的分析. 植物研究, $2007,27(3): 350-355,371$.]

[36] Xia P, Liu Q. Experience and enlightenment of protection and restoration of water ecosystem in foreign countries. Water Resources Development Research, 2011, 11(6): 72-78. [夏朋, 刘蒨. 国外水生态系统保护与修复的经验及启示. 水利 发展研究, 2011, 11(6): 72-78.] 